\title{
Çevresel Atıklarla Modifiye Edilmiş Sathi Kaplamaların Performansının Agrega-Bitüm İlişkisi Bağlamında Değerlendirilmesi
}

\author{
Murat KARACASU ${ }^{1 *}$, Kadir Berkhan AKALIN ${ }^{2}$ \\ 1,2 İnşaat Mühendisliği Bölümü, Mühendislik-Mimarlık Fakültesi, Eskişehir Osmangazi Üniversitesi, Eskişehir, Türkiye \\ ${ }^{* 1}$ muratk@ogu.edu.tr, ${ }^{2}$ kbakalin@ogu.edu.tr
}

(Geliş/Received: 31/07/2019;

Kabul/Accepted: 29/09/2019)

\begin{abstract}
Öz: Karayolu üstyapı kaplamaları genel olarak Bitümlü Sıcak Karıșım (BSK) veya sathi kaplama şeklinde üretilmektedir. Bu çalışmada düşük maliyeti sebebiyle kullanım alanı fazla olan sathi kaplamaların agrega-bitüm ilişkisi incelenmiştir. Yapılan çalışmalarda, agrega, bitüm ve karışım deney sonuçları birlikte değerlendirilmiştir. Agrega olarak kireçtaşı ve bazalt cinsi agregalar kullanılmıştır. Bitüm olarak; 50/70 ve 70/100 penetrasyonlu bitümler, katk1 olarak ise; \% 10 atık lastik ve $\% 1$ Polivinil Klorür (PVC) kullanılmıştır. Üretilen bütün bu farklı tipteki numuneler için sathi kaplamaların performansının ölçülmesinde kullanılan Soyulma ve Yapışma (Vialit) mukavemeti deneyleri gerçekleştirilmiştir. Deneysel çalışmalardan elde edilen sonuçlara göre, 50/70 bitüm kireçtaşı agregalarla daha iyi yapışma sağlarken, 70/100 bitüm bazalt agregalarda daha güçlü yapışma sağlamaktadır. Atık lastik ve PVC talaşları agrega ve bitüm arasındaki adezyonu artırmaktadır. Ayrıca atıklar kireçtaşı agregalarda daha iyi performans göstermektedir. Özellikle bazalt türü agregalarda düşük olan adezyonu, kullanılan atık lastik ve PVC talaşları artırmaktadır. 70/100 penetrasyonlu bitümde, bitümün kıvamından dolayı katkı olarak kullanılan atıkların homojen dağılmaları kolaylaşmakta ve bu sayede adezyon kuvvetindeki artış daha iyi gözlenebilmektedir. Soyulma mukavemeti kapsamında, atık lastik ile modifiye edilmiş olan bitüm ve kireçtaşı en iyi performansı sağlamıştır.
\end{abstract}

Anahtar kelimeler: Sathi kaplama, geri dönüşüm, soyulma mukavemeti, yapışma mukavemeti, sürdürülebilir ulaşım.

\section{Evaluation of the Performance of Modified Chip Seal with Environmental Waste in the Context of Aggregate-Bitumen Relationship}

\begin{abstract}
Road pavements are produced in the form of Bituminous Hot Mix Asphalt (HMA) or chip seal in general. In this study, the aggregate-bitumen relationship of chip seal, which is preferred more due to its low cost, was investigated. In experimental studies, aggregate, bitumen and mixture test results were evaluated together. Limestone and basalt aggregates were used as the aggregates. As the bitumens; 50/70 and 70/100 penetration grade bitumens, as an additive; $10 \%$ waste rubber and $1 \%$ Poly Vinyl Chloride (PVC) are used in the experiments. Peeling resistance and adhesion (Vialit plate) tests were applied to measure the performance. According to the experimental results; in the adhesion (Vialit) tests, 50/70 penetration grade bitumen provides better adhesion with limestone aggregates, while 70/100 bitumen provides better adhesion in basalt aggregates. Waste rubber and PVC fibers increase adhesion strength between aggregate and bitumen. In addition, the wastes used as additives revel a good performance when the limestone is used as an aggregate. Waste rubber and PVC fibers increase the adhesion strength which is low in basalt aggregates especially. In 70/100 penetration grade bitumen, the homogeneous dispersion of the wastes as the additives is facilitated due to the consistency of the bitumen, thus increasing the adhesion strength can be easily observed. In the context of peeling strength, limestone aggregates and the bitumen modified by the waste rubber provided the best performance.
\end{abstract}

Key words: Chip seal, recycling, peeling resistance, adhesion test, sustainable transport.

\section{Giriş}

Her geçen gün kaynakların tükendiği ve daha fazla kirlenen dünyamızda yapılan mühendislik çalışmalarında güvenlik, ekonomi ve çevreyi en az kirletme esastır. Karayolu kaplamalarında sathi kaplamaların maliyeti bitümlü sıcak karışım (BSK) kaplamalara göre daha düşüktür. Ancak imalat şekillerinden ve yapılarından dolayı bazı dezavantajlı durumları mevcuttur. Genel bir ifadeyle, sathi kaplamaları oluşturmak için, temel tabakası üzerine ince film halinde bitüm püskürtülür (Şekil 1). Daha sonrasında belli bir dane dağılımına sahip agrega, bitüm üzerine serilir. Silindirlerle ve daha sonra akan trafiğgin de etkisiyle sıkıştırma yapılır. BSK kaplamalara göre kalınlıkları daha az olduğundan ve büyük gözenekli yapısından dolayı dayanımları düşüktür. Özellikle kış aylarındaki tuzlama çalışmalarından daha fazla etkilenirler. Su ile etkileşimleri daha fazladır. Bu yüzden, araç tekerleklerindeki vakumlama etkisiyle birlikte yüzeyden kopmalar meydana gelebilir. Mevsimsel sicaklığın

\footnotetext{
${ }^{*}$ Sorumlu yazar: muratk@ ogu.edu.tr. Yazarların ORCID Numarası: ${ }^{1}$ 0000-0001-9721-0984, ${ }^{2}$ 0000-0001-6720-5498
} 
artması ile kusmalar oluşabilir ve bunun yanında yapısal bozulmalar meydana gelebilir. Kuloğlu, Kök ve Öndaş (2004) yaptığı çalışmada, sıcaklık, trafik yükü ve bitüm oranındaki artışın kusma miktarını da arttıracağını tespit etmişlerdir [1]. Ancak maliyetlerinin düşük olması nedeniyle ülkemizde kaplama olarak genellikle sathi kaplamaların kullanımı tercih edilmektedir. Özellikle ülkemizde kırsal alanlardaki ilçe ve köy yolarında yaygın olarak kullanılmaktadır. Tablo 1'de verildiği üzere ülkemizde sathi kaplama yol uzunluğu $40.183 \mathrm{~km}$ 'dir ve tüm yol ağının yaklaşık \%60’ını oluşturmaktadır.

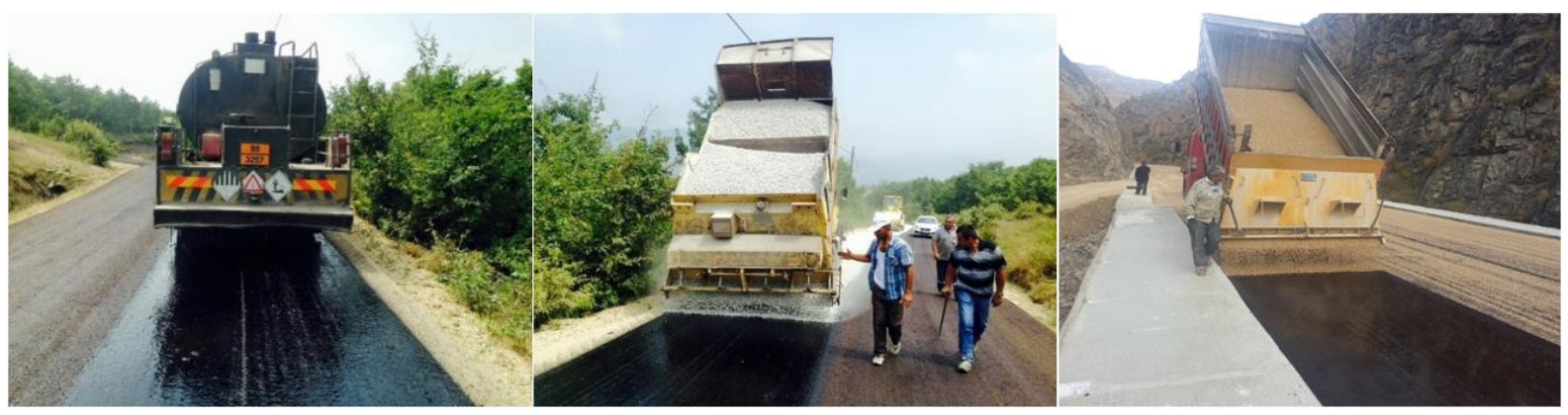

Şekil 1. Sathi kaplama çalışmaları.

Tablo 1. Satıh Cinsine Göre Türkiye Karayolu Ağı (01.01.2019 itibariyle) [2].

\begin{tabular}{|l|c|c|c|c|c|c|c|}
\cline { 2 - 8 } \multicolumn{1}{c|}{} & Asfalt Betonu & Sathi Kaplama & Parke & Stabilize & Toprak & Diğer Yollar & TOPLAM \\
\hline Otoyol & 2159 & - & - & - & - & - & 2159 \\
\hline Devlet Yolları & 17520 & 13115 & 58 & 27 & - & 301 & 31021 \\
\hline İl Yolları & 4403 & 26218 & 232 & 537 & 443 & 2320 & 34153 \\
\hline TOPLAM & 24082 & 39333 & 290 & 564 & 443 & 2621 & 67333 \\
\hline
\end{tabular}

Eğer yol imalatı hızlı bir şekilde yapılacak ise, BSK kaplama yolları önce sathi kaplama şeklinde imal edip, muhtemel oturmalar gerçekleştikten sonra asıl kaplamayı inşa etmek daha faydalı olacaktır. Sathi kaplamaların kullanımı bu kapsamda da önem arz etmektedir.

Literatürdeki çalışmalara bakıldığında, Türkyılmaz (2007) tarafından yapılan çalışmada sathi kaplamalar da dâhil olmak üzere, esnek üstyapılı karayolları için dünyada uygulanan koruyucu bakım yöntemleri incelenmiş ve uygulanabilirliği araştırılmıştır. Bu kapsamda esnek üstyapılı karayollarında koruyucu bakım yönteminin seçimi hakkında bilgiler sunulmuş ve karayollarında oluşan bozulmalar ve nedenleri araştırılmıştır [3].

Gürer (2010) tarafından yapılan ve sathi kaplamaların performansına etki eden parametrelerin araştırıldığ çalışmada, agrega ve bitüm numuneleri üzerinde laboratuvar ortamında, Nicholson ve California soyulma deneyleri ile Vialit ve Modifiye yapışma deneyleri gerçekleştirilmiştir. Ayrıca iklimsel veriler ve laboratuvar ortamında tespit edilen malzeme özellikleri kullanılarak, sathi kaplama performansı üzerinde etkili olduğu düşünülen parametreler için model geliştirilmiştir [4].

Sağlık ve Öztürk tarafından 2014 yılında Türkiye'deki sathi kaplamalarda kullanılan bitümlerin performans sınıflarının (SPG -Surface Performance Grade) belirlenmesi üzerine çalışma yapılmıştır. Bu çalışma kapsamında, maksimum ve minimum kaplama sıcaklıklarına göre uygulanacak sathi kaplamada, hangi bitümün kullanılacağı araştırılmıştır [5].

Gürer ve Karaşahin (2014) sathi kaplamada kullanılan agregaların adezyon özelliklerini incelediği araştırmasında, sathi kaplamaların performansına etkiden en önemli faktörün agrega-bitüm arasındaki adezyon olduğunu ifade etmektedir. Agrega-bitüm arasındaki yeterli yapışma kuvvetinin sağlanması ile agregaların kaplama yüzeyinden sökülmeleri azalacak ve bu sayede sathi kaplamaların performansı artarak, hizmet süresini sorunsuzca karşılaması sağlanacaktır [6].

Literatürde yapılan çalışmalar daha çok BSK kaplamalar üzerine yoğunlaşmakta, sathi kaplamaların performanslarının araştırılmasına yönelik çalışmalar oldukça azdır. Bu kapsamda sathi kaplamalar üzerinde çalışmalar yapılmış ve deneyler gerçekleştirilmiştir. Bu çalışmada, agrega-bitüm adezyonu üzerine araştırmalar yapmak ve bu araştırma sonuçlarını ortaya koymak amaçlanmıştır. 50/70 ve 70/100 penetrasyonlu bitümler için 
deneyler ayrı ayrı uygulanmıştır. Ülkemizde yaygın olarak kullanılan kireçtaşı ve maliyeti daha yüksek olan bazalt agregaları da deneylerde kullanılmıştır. Atık katkı malzemesi olarak; atık lastik ve Poli Vinil Klorür (PVC) talaşları ile deneysel çalışmalar gerçekleştirilmiştir. Sathi kaplamaların performans değerlerinin ölçülmesinde kullanılan Soyulma ve Vialit yapışma deneyleri, iki farklı tip bitüm, iki farklı türde agrega ve değişken katkı miktarı uygulanarak gerçekleştirilmiştir.

\section{Materyal ve Metot}

Çalışma kapsamında agrega, bitüm ve karışım deney sonuçları birlikte değerlendirilmiş̧tir. Çalışmanın akış şeması Şekil 2'de verilmiştir. Agrega olarak, kireçtaşı ve bazalt cinsi agregalar; Bitüm olarak, 50/70 ve 70/100 penetrasyonlu bitümler; katkı olarak ise $\% 10$ oranında atık lastik ve \%1 oranında PVC kullanılmıştır. Öncelikli olarak arasındaki ilişsinin değerlendirileceği, agrega ve bitüm numuneleri üzerinde ayrı ayrı deneyler gerçekleştirilmiş ardından agrega-bitüm ilişkisi için deneyler yapılmıştır.

Agregalar için, elek analizi, Los Angeles aşınma kaybı, Mikro-Deval aşınma kaybı, yassılık indeksi, donmaçözülme, organik madde analizi, birim hacim ağırlık, özgül ağırlık ve su emme deneyleri; bitüm için, yumuşama noktası, penetrasyon, düktilite, ince film 1sıtma kaybı (TFOT), parlama noktası ve özgül ağırlık deneyleri uygulanmıştır. Atık katkılarla üretilen ve agrega-bitüm ilişkisi incelenen farklı tipteki numuneler için sathi kaplamaların performansının ölçülmesinde kullanılan Soyulma ve Yapışma (Vialit) mukavemeti deneyleri gerçekleştirilmiştir.

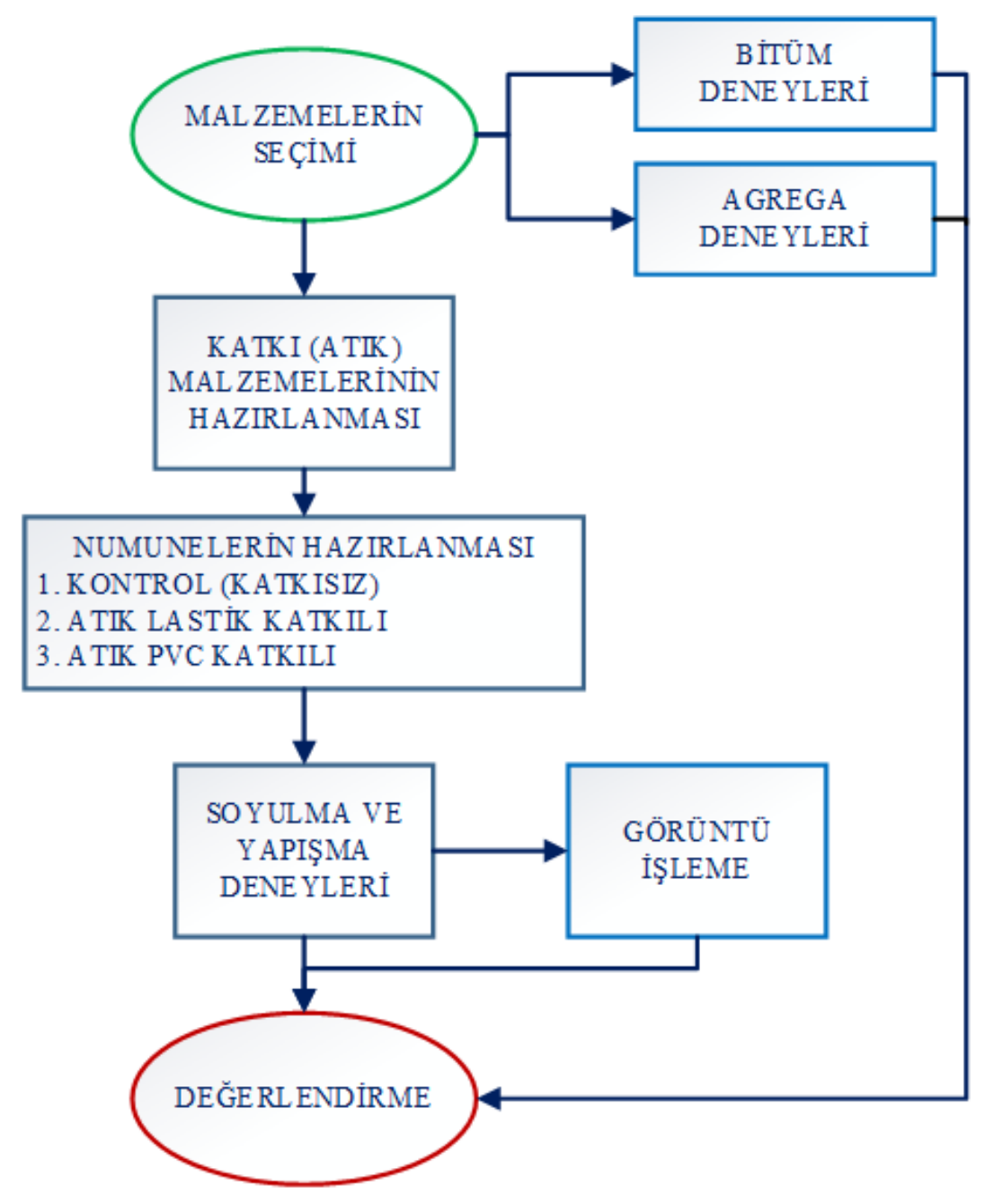

Şekil 2. Çalışmanın akış şemasıı. 
Soyulma mukavemeti deneyi, agregaların soyulma dayanımını ölçmek için gerçekleştirilen deneydir. Su ve trafik etkisi agrega ile bitüm arasındaki adezyonu bozarak bitümün agrega üzerinden soyulmasına sebep olur. Soyulma dayanımı; agrega ile bitüm arasındaki yapışma özelliğinin bir ölçüsüdür. Soyulma deneyinde; 9,50-4,75 mm elek aralığında kalan agregalardan 200 gram alınarak iyice yıkanır ve $110^{\circ} \mathrm{C}^{\prime}$ lik etüvde kurutulur. $50 \pm 0,5$ gram

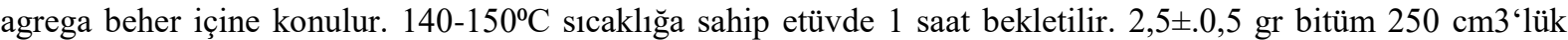
beher içerisine konulur. Beher kum banyosuna yerleştirilir. Agregalar beher içerisine dökülür ve agrega yüzeyleri homojen bir şekilde kaplayıncaya kadar baget ile karıştırılır. İçinde bitüm ve agrega karışımı olan beher, $60^{\circ} \mathrm{C}^{\prime}$ lik etüvde 24 saat bekletilir. Daha sonra üzerleri bitüm kaplı olan agregalar $10 \mathrm{~cm}$ çapındaki petri kaplarına yerleştirilir. Gerekirse agregaların yüzeyleri cam bagetler ile düzeltilebilir. Petri kaplarının içerisine saf su ilave edilir ve kapakları kapatılır. $60^{\circ} \mathrm{C}$ lik etüvde 24 saat bekletilir. Sonrasında petri kaplarının suyu boşaltılarak yeniden su ile doldurulur. Petri kaplarına yandan ş̧ık verilerek agrega yüzeyleri görsel olarak incelenir. Agregaların soyulan ve soyulmayan kısımları belirlenir. Soyulmayan kısımların, tüm agrega yüzeyine oranı soyulma dayanımını verir.

Vialit yapışma mukavemeti deneyi, agrega-bitüm adezyonu hakkında bilgi veren bir deneydir. Özellikle sathi kaplamalarda agrega ile bitüm arasındaki adezyon kuvveti oldukça önemlidir. Mevsimsel değişikliklerin fazla yaşandığı bölgelerde agrega-bitüm ilişkisinin önemi daha da artacaktır. Vialit deneyinde; $19 \mathrm{~mm}$ (3/4")'lik elekten geçen, 9,5mm (3/8") elek üstünde kalan agregalardan 100 adet y1kanır ve kurutulur. Agregalar, agrega sericinin içerisindeki kafeslere yerleştirilir. Agregaların düşmemesi için altında düz yüzeyli çelik levha bulunmalıdır. Deneyde kullanılacak bitüm $150^{\circ} \mathrm{C}$ 'de 2 saat isıtılır. Çelik levhalar da aynı sıcaklıkta 30 dakika 1sitılır. 40 gram bitüm spatula yardımıyla çelik levhalar üzerine serilir. Agrega sericide yer alan, bölmelenmiş kafesin altında yer alan çelik levha hızla çekilir ve agregaların çelik levha üzerine serbest düşmesi sağlanır. Agregaların bitüme yapışması için 2-3 dakika beklenir. Lastik bandajlı silindir ile agregaların üzerinden birbirine dik yönde, her gidişgeliş bir geçiş olmak üzere, üçer defa geçiş yapılır. Bu işlem sırasında agregaların yerinden oynamamasına dikkat edilir. Bu deney levhalarından 3 adet hazırlanır. Üzerinde bitüm ve agrega serili olan bu 3 levha oda sıcaklığında 1 saat bekletilir. Ardından levhalar $35^{\circ} \mathrm{C}^{\prime}$ lik su banyosunda 24 saat bekletilir. Levhalar, yatay konumdaki düssme tablanın üç mesnedine agregaların olduğu yüzey altta kalacak şekilde yerleştirilir. Çelik bilye, $50 \mathrm{~cm}$ yükseklikten levha üzerine, 10 saniye içerisinde 3 defa düşürülür. Bu işlem her üç numune levhası için tekrarlanır ve levhalardan düşen agrega miktarları belirlenir.

Çalışma kapsamında katkı maddesi olarak atık lastik ve PVC kullanılmıştır. Atık lastikler, hizmet ömrünü tamamlayan atık lastiklerden elde edilmektedir (Şekil 3). Atık lastiklerde araç tekerleklerinin yüzeye değen yumuşak kısım ve çelik tel ile sağlamlaştırılmış sert kısım olmak üzere iki kısım bulunmaktadır. Çalışmada atık lastiklerin yumuşak kısmı kullanılmıştır. Bu yumuşak kısımlar; birbirine paralel, yüzeyleri pürüzlü, yüksek devirde dönen, çelik plakalar vasıtasıyla ögütülmektedir. Ögütülmüş toz halindeki atık lastikler bitüm ile yaklaşı 250 devir/dak. hızda modifikatör mikserde karıştırılmaktadır (Şekil 4). Modifikatör karıştırıcı 1sı iletken bir hazneye sahiptir. Bu 1sı iletkenlik özelliğine sahip yağ haznesi sayesinde istenilen yüksek sıcaklık değerleri kolaylıkla sağlanabilmektedir. Karışım sıcaklığı $163^{\circ} \mathrm{C}$, karışım süresi 60 dakikadır.

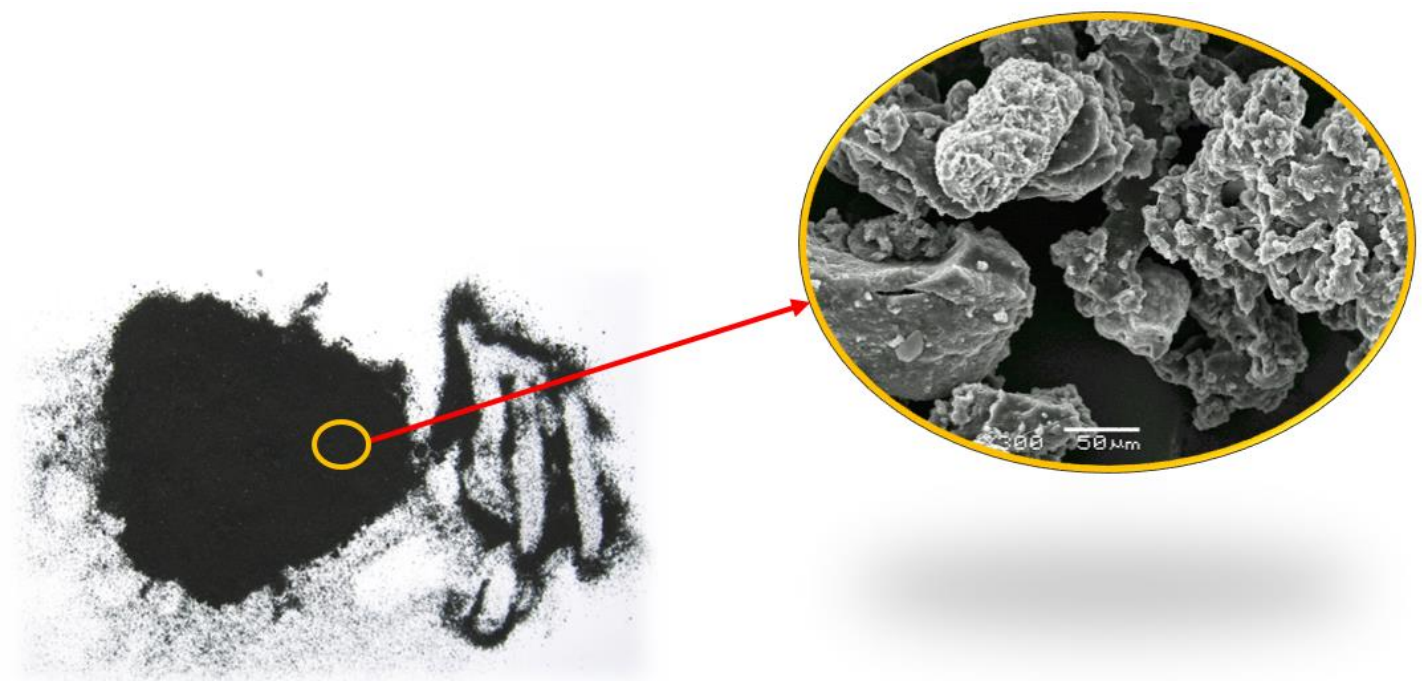

Şekil 3. Atık lastik katkı. 
PVC (Poli Vinil Klorür) talaşları petrol ve tuzdan oluşan, endüstriyel olarak genellikle kapı ve pencere yapımında kullanılan sentetik bir malzemedir. Çalışmada kullanılan PVC talaşları, üretim sırasında tezgâhların çevresinde atık olarak biriken malzemelerdir. Bu atık PVC talaşları 1x5 mm boyutlara sahip ve beyaz renktedir (Şekil 4).
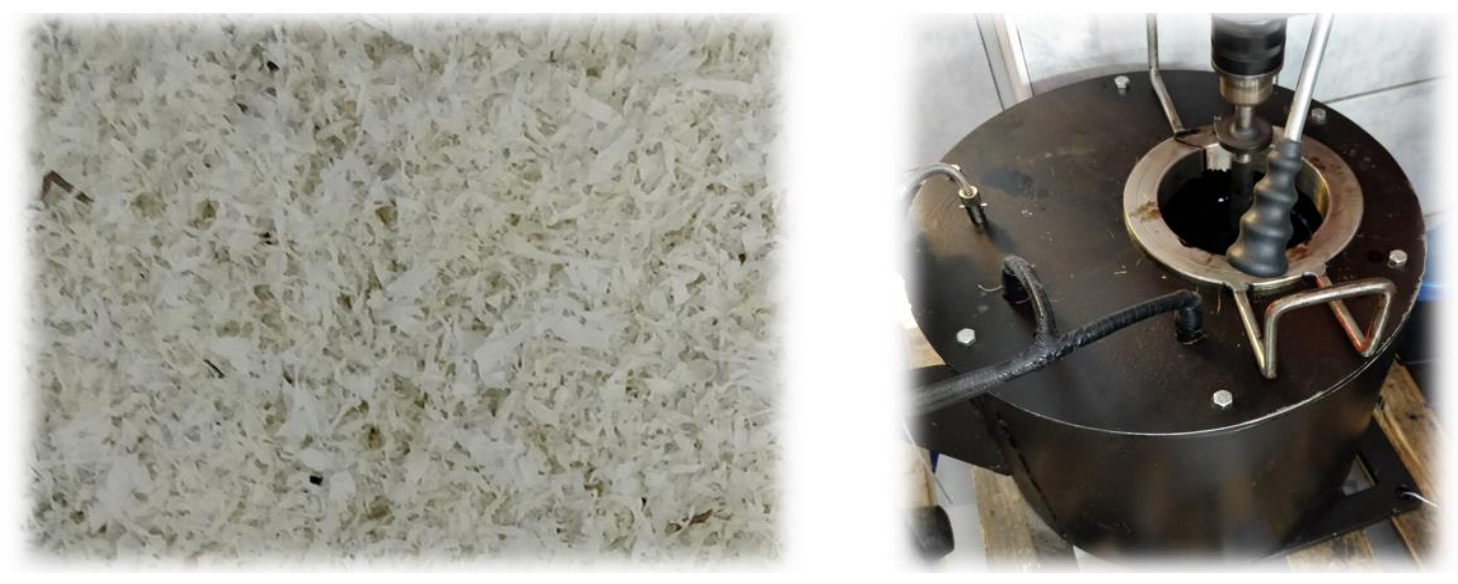

Şekil 4. Atık PVC katkı ve bitüm katkı karışım cihazı (modifikatör).

\section{Deneysel Çalışma Sonuçları}

Çalışma kapsamında gerçekleştirilen agrega deneyleri TS EN standartlarına göre yapılmıştır. Agregalar için elde edilen deney sonuçları Tablo 2'de verilmiştir. Çalışmada gerçekleştirilen soyulma ve yapışma deneyleri kaba agregalar ile yapıldığından dolayı, agrega deneyi kireçtaşı ve bazalt kaba agregaları için uygulanmıştır.

Tablo 2. Agrega özellikleri deney sonuçları.

\begin{tabular}{|c|c|c|c|c|}
\hline & Kireçtaşı & Bazalt & Sınır Değer & Standart \\
\hline Hacim özgül ağırlık $\left(\mathrm{g} / \mathrm{cm}^{3}\right)$ & 2,480 & 2,665 & & \multirow{4}{*}{ TS EN 1097/6 } \\
\hline Zahiri özgül ağırlık (g/cm³) & 2,657 & 2,718 & & \\
\hline $\begin{array}{l}\text { Yüzey kuru suya doygun (YKSD) } \\
\text { özgül ağırlık }\left(\mathrm{g} / \mathrm{cm}^{3}\right)\end{array}$ & 2,547 & 2,685 & & \\
\hline Su emme yüzdesi (\%) & 1,687 & $\mathbf{0 , 7 3 0}$ & & \\
\hline Sıkışık birim hacim ağırlık $\left(\mathrm{g} / \mathrm{cm}^{3}\right)$ & 1,911 & 2,456 & & \multirow{2}{*}{ TS 3529} \\
\hline Gevşek birim hacim ağırlık $\left(\mathrm{g} / \mathrm{cm}^{3}\right)$ & 1,756 & 2,037 & & \\
\hline Aşınma kaybı (\%) & 26,2 & 24,7 & $<30$ & TS 3694 \\
\hline Yassılık indeksi (\%) & 17 & 16 & $<35$ & TS 9582 \\
\hline Don kaybı $\left(\mathrm{MgSO}_{4}\right)(\%)$ & 1,3 & 0,9 & $<10$ & TS 3655 \\
\hline Organik madde tayini & - & - & $<0,5$ & TS 3673 \\
\hline
\end{tabular}

Yapılan çalışmada kullanılan 50/70 ve 70/100 penetrasyonlu bitümler için TS EN standartlarına göre uygulanan deney sonuçları Tablo 3’te verilmiştir. 
Tablo 3. Bitüm özellikleri deney sonuçları.

\begin{tabular}{|l|c|c|c|c|c|}
\cline { 2 - 5 } \multicolumn{1}{c|}{} & $\mathbf{5 0 / 7 0}$ & $\mathbf{7 0 / 1 0 0}$ & \multicolumn{2}{|c|}{ Sinır Değer } & \multirow{2}{*}{ Standart } \\
\cline { 4 - 5 } & Bitüm & Bitüm & $50 / 70$ & $70 / 100$ & \\
\hline Yumuşama noktası $\left({ }^{\circ} \mathrm{C}\right)$ & $\mathbf{4 8 , 5}$ & $\mathbf{4 7 , 0}$ & $46-54$ & $43-51$ & TS 120 EN 1427 \\
\hline Penetrasyon $\left(25^{\circ} \mathrm{C}, 1 / 10 \mathrm{~mm}\right)$ & $\mathbf{5 8 , 5}$ & $\mathbf{7 6 , 1}$ & $50-70$ & $70-100$ & TS 118 EN 1426 \\
\hline Parlama noktası $\left({ }^{\circ} \mathrm{C}\right)$ & $\mathbf{2 5 0}$ & $\mathbf{2 7 0}$ & $>230$ & $>230$ & TS 123 EN 22592 \\
\hline $\begin{array}{l}\text { Isitma kayb1 }(\text { TFOT kütle } \\
\text { kayb1) }(\%)\end{array}$ & $\mathbf{0 , 1 3}$ & $\mathbf{0 , 1 8}$ & $<0,5$ & $<0,8$ & $\begin{array}{c}\text { TS } 121 \\
\text { TS EN } 12607 / 2\end{array}$ \\
\hline Özgül ağırlık $\left(\mathrm{g} / \mathrm{cm}^{3}\right)$ & $\mathbf{1 , 0 4 8}$ & $\mathbf{1 , 0 2 7}$ & $1,0-1,1$ & $1,0-1,1$ & TS 1087 \\
\hline
\end{tabular}

Soyulma mukavemeti deney çalışmaları için her bir numuneden ikişer adet üretilmiş ve sonuçlar değerlendirilirken aynı özelliğe sahip numunelere ait değerlerin ortalamaları alınmıştır. Numunelerin içeriklerine göre yapılan isimlendirme Tablo 4'te, deney çalışmasına ait görseller Şekil 5'te verilmiştir. Geleneksel olarak agrega-bitüm arasındaki soyulma mukavemeti TS EN 12697-11'e göre, deney sonundaki tüm agrega danelerinin soyulmamış yüzeylerinin, bütün yüzeye oranının en yakın \%5'e yuvarlanması ile tespit edilir [7]. Ancak bu değer, günümüzde birçok alanda yaygın olarak kullanılan görüntü işleme yöntemleri ile tespit edilebilmektedir (Şekil 6). Buna uygun olarak soyulma mukavemeti değerleri Şekil 7'de, görüntü işleme yöntemleri kullanılarak daha hassas olarak tespit edilmiş ve bulunan değerler gözle de kontrol edilmiştir.

Tablo 4. Numune isimlendirmelerine göre numunelerin içerikleri.

\begin{tabular}{|c|c|c|c|}
\hline Numune Adı & Bitüm Sinıfi & Agrega Tipi & Katkı \\
\hline $5070-B-K$ & $50 / 70$ & Bazalt & Katkısız \\
\hline $5070-B-L$ & $50 / 70$ & Bazalt & Atık lastik \\
\hline $5070-B-P$ & $50 / 70$ & Bazalt & PVC talaşları \\
\hline $5070-K-K$ & $50 / 70$ & Kireçtaş1 & Katkısız \\
\hline $5070-K-L$ & $50 / 70$ & Kireçtaş1 & Atık lastik \\
\hline $5070-K-P$ & $50 / 70$ & Kireçtaşı & PVC talaşları \\
\hline $70100-B-K$ & $70 / 100$ & Bazalt & Katkısız \\
\hline $70100-B-L$ & $70 / 100$ & Bazalt & Atık lastik \\
\hline $70100-B-P$ & $70 / 100$ & Bazalt & PVC talaşları \\
\hline $70100-K-K$ & $70 / 100$ & Kireçtaş1 & Katkısız \\
\hline $70100-K-L$ & $70 / 100$ & Kireçtaş1 & Atık lastik \\
\hline $70100-K-P$ & $70 / 100$ & Kireçtaş1 & PVC talaşları \\
\hline
\end{tabular}


Murat KARACASU, Kadir Berkhan AKALIN
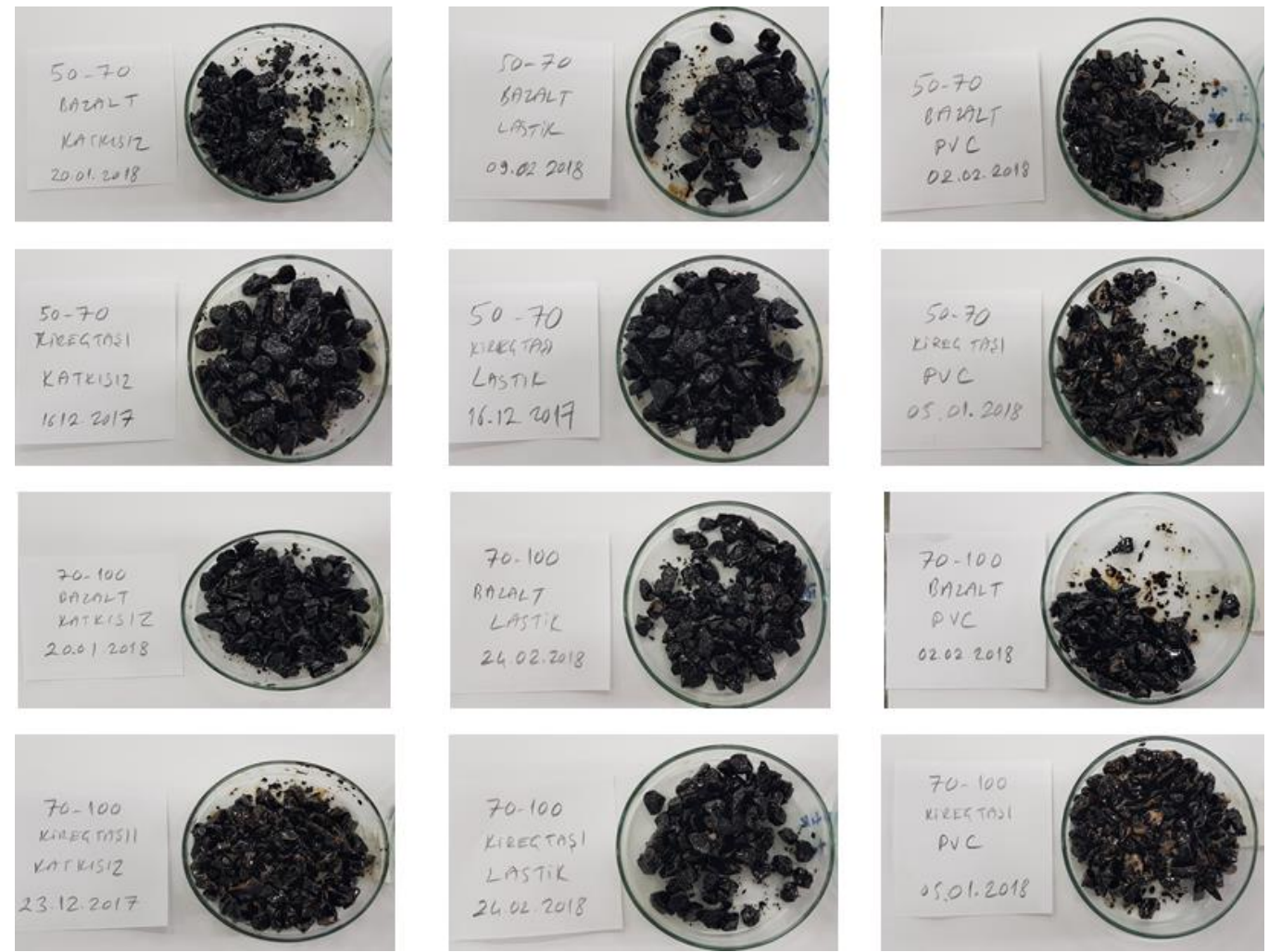

Şekil 5. Soyulma deneyi görüntüleri.

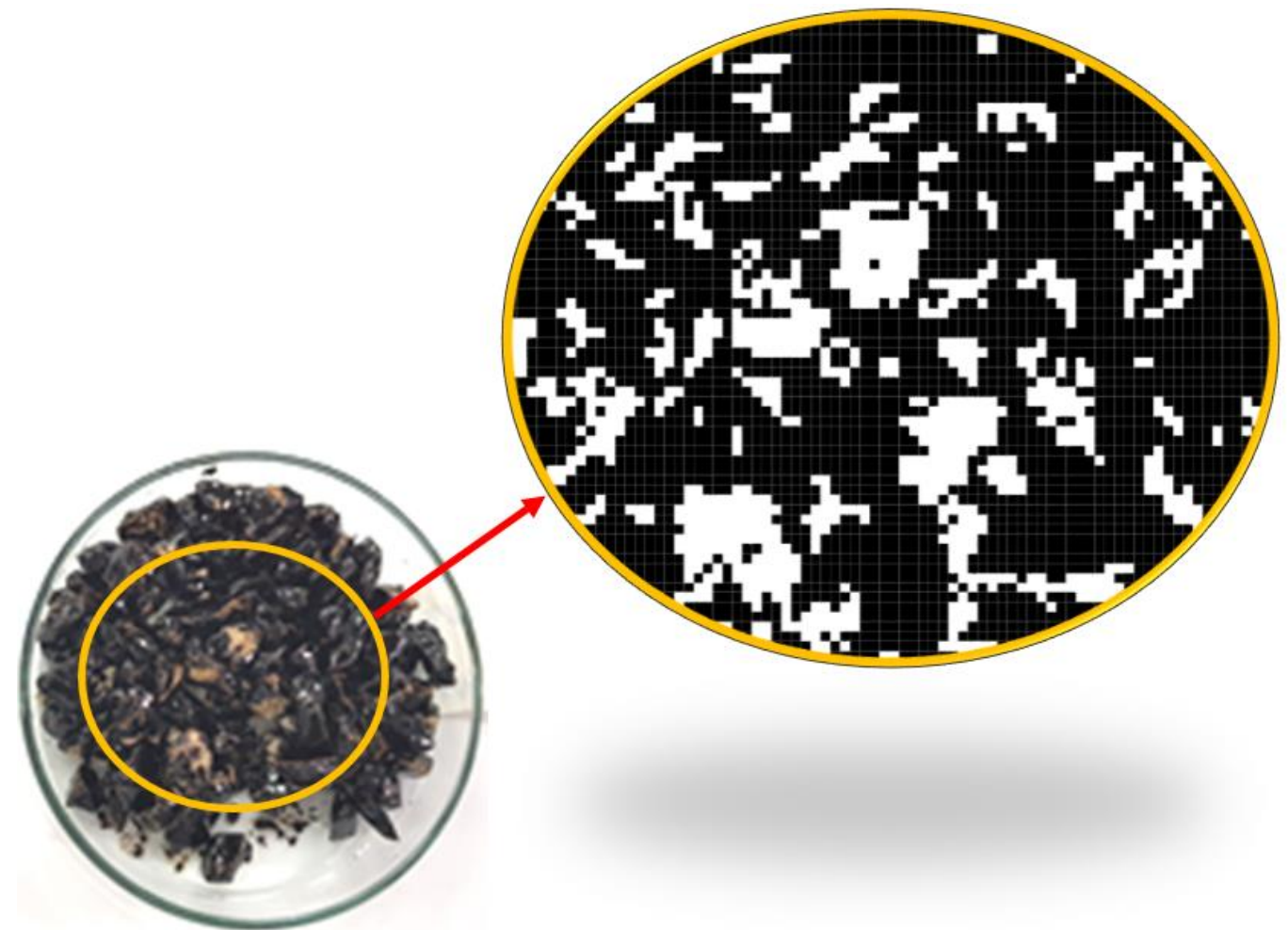

Şekil 6. Görüntü işleme yöntemleri kullanılarak soyulma mukavemeti değerinin tespiti. 


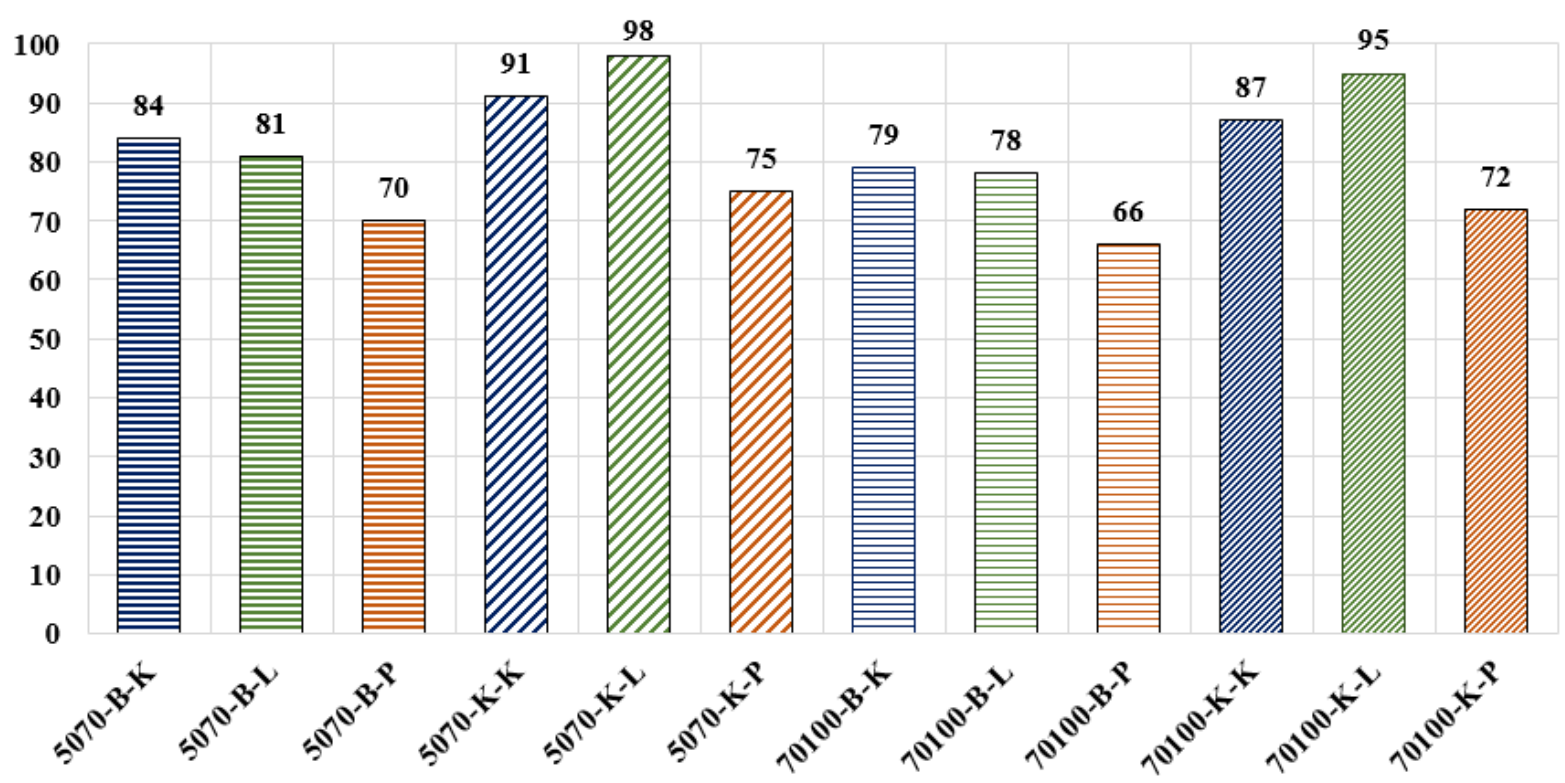

Şekil 7. Soyulma mukavemeti değerleri (\%).

Deney sonuçlarına göre, atık lastik ile modifiye edilmiş olan bitüm ve kireçtaşı en iyi performansı sağlamıştır. PVC talaşı atıklarının soyulma performansına olumlu etkisi bulunmamaktadır. Soyulma mukavemeti bağımlı değişken, agrega, bitüm ve katkı türleri bağımsız değişken olarak düşünüldüğünde, ikili değerlendirmelerde farklı sonuçlar ortaya çıkabilmektedir. Katkı maddesi, bitüm ile agreganın bağlanmasına olumlu etki gösteriyorsa kaplamanın soyulma mukavemetini de arttıracaktır. PVC talaşı katkının soyulma mukavemetini arttırmıyor olmasına, mevcut karıştırma sıcaklığında PVC'nin yeterli bağlayıcı özellik gösterememiş olması neden olarak gösterilebilir. Atık lastikler hem 50/70 hem de 70/100 bitüm ile kireçtaşı agrega arasında iyi bir bağlayıcı olarak çalışmakta ve soyulma mukavemetini artırmaktadır. Kireçtaşı agrega yüzeyinin bazalt agrega yüzeyine göre daha fazla gözenekli yapıda olması, soyulma mukavemeti açısından kireçtaşının bazalta göre daha iyi sonuçlar vermesini sağlamaktadır. Ayrıca literatürdeki bazı çalışmalarda kireçtaşının bazalta göre bitümle daha iyi uyum sağlamasının nedenlerinden birinin de pH (asidik-bazik) uyumu olduğu düşünülmektedir [8-10].

Vialit yapışma mukavemeti için yapılan deneysel çalışmalarda yine her bir numuneden üçer adet üretilmiş ve sonuçlar değerlendirilirken aynı özelliğe sahip numunelere ait değerlerin ortalamaları alınmıştır. Numunelerin isimlendirmeleri soyulma mukavemetindeki isimlendirmelerle aynıdır (Tablo 4). Deney çalışmasına ait görseller Şekil 8'de, adezyon yüzdeleri Şekil 9'da verilmiştir.
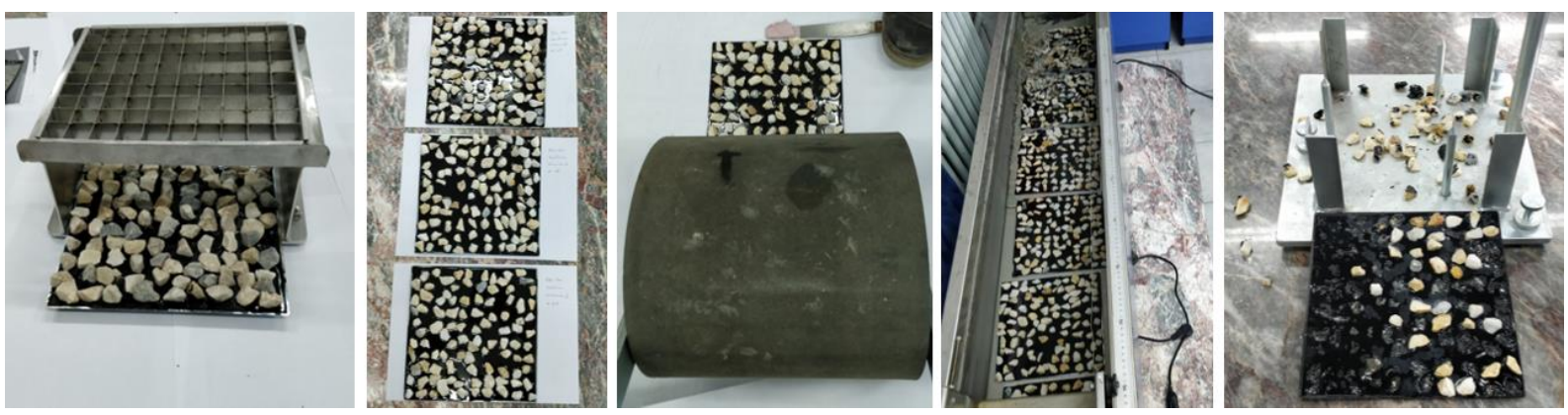

Şekil 8. Vialit yapışma deneyi görüntüleri. 


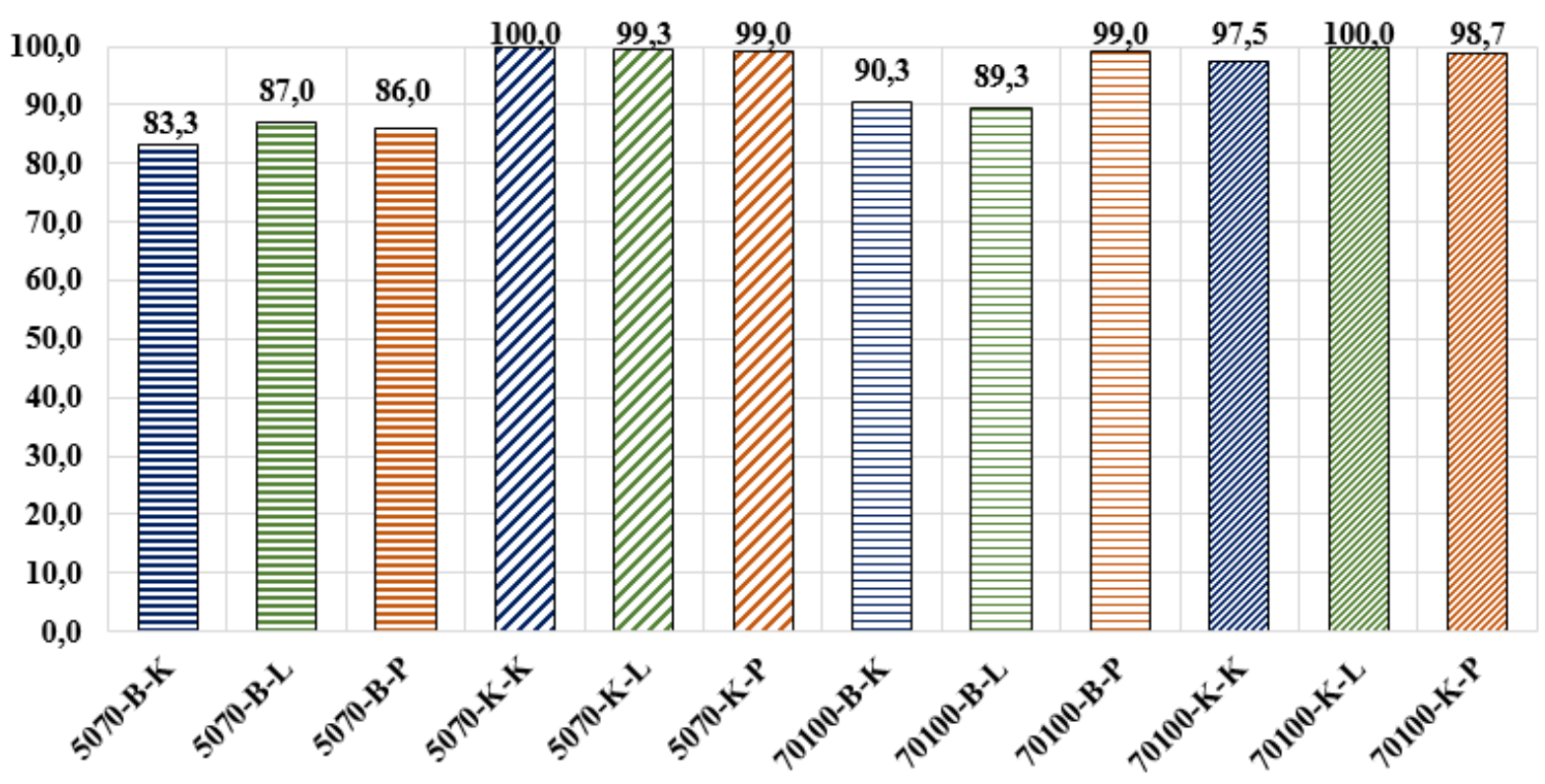

Şekil 9. Vialit yapışma (adezyon) mukavemeti değerleri (\%).

Deney sonuçları incelendiğinde, kireç taşı ile üretilen numuneler yapışma performansı bağlamında daha iyi sonuçlar vermektedir. Kireçtaşı agregalar bazalt agregalara göre daha gözenekli bir yapıya sahip olduklarından dolayı, bitüm bu gözenekli yapıya daha iyi tutunabilmekte ve adezyon kuvvetinde artış sağlanabilmektedir. Katkılar, kireçtaşı agrega ile daha iyi bağlayıcı özellik göstermekte ve bu sayede adezyon kuvvetini arttırdığı gözlemlenmektedir. Kullanılan katkıların 70/100 bitümün kıvamı nedeniyle, bitüm içerisinde daha homojen dağıldığı ve bu sebeple etkileşiminin arttığı düşünülmektedir. Kireçtaşı bütün katkı ve bitüm türleri için şartname sınır değerlerini sağlamaktadır. Masif yapısı ve düzgün yüzeyinden dolayı bazalt agregalar adezyon açısından sorun yaratmakta, ancak 70/100 bitüm ile daha iyi sonuç verebilmektedir.

\section{Sonuçlar ve Yorumlar}

Çalışma kapsamında maliyeti bitümlü sıcak karışım (BSK) kaplamalara göre daha düşük olan ve ülkemizde özellikle il ve köy yollarında yaygın olarak uygulanan sathi kaplamalarda kullanılabilecek çevresel atıklarla modifiye edilmiş bitüm ile agregalar arasındaki ilişkisi kapsamında değerlendirmeler yapılmıştır. Sathi kaplamaların performanslarının değerlendirilmesinde sıklıkla kullanılan soyulma mukavemeti ve Vialit yapışma (adezyon) mukavemeti deneyleri esas alınmıştır.

Sathi kaplamalar yapısı itibariyle çevresel şartlardan BSK'lara göre daha fazla etkilenirler. Ancak yapılacak yolun hızlıca hizmete açılması gerektiğinden, yolun sınıfina da uygun olarak, başlangıçta sathi kaplama uygulaması yapılarak gelecek yıllarda BSK'ya dönüştürülebilmektedir. Bu sayede meydana gelebilecek oturmalar ve ondülasyonlar gözlemlenerek BSK uygulaması sırasında var olan bozulmaların telafi edilmesi de sağlanabilmektedir. Literatürde, yapılan çalışmaların daha çok BSK kaplamalar üzerine yoğunlaştığı, sathi kaplamalar üzerine gerçekleştirilen araştırmaların oldukça az olması da göz önünde bulundurularak yapılan bu çalışmanın literatüre etkin bir katkısının olacağı açıktır.

Çalışmada soyulma ve yapışma mukavemeti bağımlı değişken, agrega, bitüm ve katkı türleri bağımsız değişken olarak ele alınmıştır. Agrega olarak ülkemizde oldukça yaygın kullanılan kireçtaşı ve bazalt; bitüm olarak 50/70 ve 70/100 penetrasyonlu bitümler; katkı olarak ise $\% 10$ atık lastik ve \%1 PVC bitüm ile modifiye edilerek kullanılmıştır.

Soyulma ve yapışma mukavemeti deneyleri, Karayolları Teknik Şartnamesi (KTŞ) esas alınarak, şartnamede belirtilen standartlara uygun olarak gerçekleştirilmiş̧tir [11]. Her bir tür numuneden soyulma deneyi için ikişer tane, yapışma deneyi için üçer tane ve birer tane yedek hazırlanmıştır. Gerçekleştirilen deneysel çalışmalar görüntü işleme teknikleri ile desteklenmiştir. 
Deneysel çalışmalardan elde edilen sonuçlar aşağıdaki gibi sıralanabilir:

Vialit yapışma mukavemeti deneylerinde, kireçtaşı numuneleri bazalt numunelere göre daha iyi performans göstermiştir. Kireçtaşı ile üretilen numunelerde agrega-bitüm adezyonu daha fazla çıkmaktadır. Bu durum agreganın yapısı ile açıklanabilir. Kireçtaşı agregalar gözenekli yapısı sayesinde bitümün agrega yüzeyine tutunmasını sağlamakta ve böylelikle adezyonu arttırmaktadır.

Penetrasyon değerlerine bağlı olarak, 50/70 ve 70/100 bitümün agrega ve bitüm adezyonuna etkileri farklılık göstermektedir. 50/70 bitüm kireçtaşı agregalarla daha fazla adezyon sağlarken, 70/100 bitümün bazalt agregalarla olan adezyonu daha fazladır. 70/100 penetrasyonlu bitümde, kıvamından dolayı ilave edilen atık katkılar bitüm içerisinde daha homojen dağılabilmekte ve bu sayede adezyon kuvvetinde 50/70 bitüme oranla daha fazla artış gözlenebilmektedir.

Katkı olarak kullanılan atık lastik ve PVC talaşları, agrega ve bitüm arasındaki adezyon kuvvetini arttırmaktadır. Ayrıca atıklar kireçtaşı agregalarda daha iyi performans göstermektedir. Özellikle bazalt türü agregalarda düşük olan adezyonu, kullanılan atık lastik ve PVC talaşları arttırmaktadır. Ancak atık lastiklerin olumlu etkisi, PVC talaşlarına oranla daha fazladır.

Soyulma mukavemeti açısından, atık lastik ile modifiye edilmiş olan bitüm ve kireçtaşı en iyi performansı sağlarken, PVC talaşlarının soyulma performansına olumlu etkisi gözlemlenmemiştir.

Çalışma sonucunda, atık lastik ile modifiye edilmiş bitüm ve kireçtaşı agrega kullanılarak üretilecek sathi kaplamanın soyulma ve yapışma mukavemeti açısından performansının diğerlerine göre en yüksek olduğu tespit edilmiștir. Kaynakların etkin kullanımı ve sürdürülebilirlik kapsamında, atık lastik kullanımı ile çevresel bir atık değerlendirilirken, atık lastiğin bitüme karışmasının oldukça kolay olması sayesinde, asfalt karıșım tesisinde yapılacak düşük maliyetli teknik değişiklikler ile üretim yapılması sağlanabilecektir. Böylelikle hem üretilen sathi kaplamaların performansının ve dolaylı olarak trafik güvenliğinin artması sağlanacak, hem de sürdürülebilir kalkınma çalışmalarına destek verilmiş olacaktır.

\section{Teşekkür}

Bu makale çalışması, Eskişehir Osmangazi Üniversitesi Bilimsel Araştırma Projeleri Koordinasyon Birimi tarafından 2016-1116 proje numarası ile desteklenen projeden üretilmiştir.

\section{Kaynaklar}

[1] Kuloğlu N, Kök BV. Öndaş M. Sathi kaplamalarda kusma olayına etki eden faktörler. 4. Ulusal Asfalt Sempozyumu, 2004; Ankara, Türkiye. pp. 141-148.

[2] Yol Ağı Bilgileri; http://www.kgm.gov.tr/Sayfalar/KGM/SiteTr/Kurumsal/YolAgi.aspx: Karayolları Genel Müdürlüğü, 2019.

[3] Türkyılmaz A. Esnek Üstyapılı Karayollarında Koruyucu Bakım Yöntemlerinin İncelenmesi. Doktora Tezi, Fen Bilimleri Enstitüsü, İstanbul Teknik Üniversitesi, İstanbul, 2007.

[4] Gürer C. Sathi kaplamaların performansına etki eden parametrelerin incelenmesi ve performans modeli geliștirilmesi. Yüksel Lisans Tezi, Süleyman Demirel Üniversitesi, Isparta, 2010.

[5] Sağlık A, Arıkan Öztürk E. Türkiye'de sathi kaplamalarda kullanılan bitümlerin performans sınıflarının belirlenmesi. Gazi Üniversitesi Mühendislik-Mimarlık Fakültesi Dergisi 2014; 29(4): 689-698.

[6] Gürer C, Karaşahin M. Sathi kaplama agregalarının adezyon özelliklerinin araştıılması. Yapı Teknolojileri Elektronik Dergisi 2014; 10(2): 1-11.

[7] TS EN 12697-11; Bitümlü karışımlar-Deney metotları-Sıcak karışımlı asfalt için-Bölüm 11: Agrega ve bitüm arasındaki bağlanmanın tayini. Türk Standardları Enstitüsü, 2012.

[8] Radenberg M, Nytus N, Diedel R, Miehling M, Boetcher S. New findings in relation to adhesion. 6th Eurasphalt \& Eurobitume Congress; 1-3 June 2016; Prague, Czech Republic. pp. 1-12.

[9] Labib ME, Hefer A, Little D. Surface Chemistry at the Bitumen-Aggregate Interface. International Conference on Advanced Characterisation of Pavement and Soil Engineering Material, Athens, Greece, 2007.

[10] Curtis CW. Investigation of asphalt-aggregate interactions in asphalt pavements. American Chemical Society, Fuel, 1992; 37: 1292-1297.

[11] Karayolu Teknik Şartnamesi. Karayolları Genel Müdürlüğü, T.C. Bayındırlık ve İskân Bakanlığı, 2013. 